\title{
A kokesi babák kultúrtörténeti aspektusai
}

\author{
TóTH-VÁsÁRHELYI RÉKA - RÁCZ IBOLYA
}

\begin{abstract}
A japán babakultúra évezredes múltra visszatekintö nagyon gazdag világ, amely jól mutatja a szigetország gazdasági, illetve kulturális erejét, lakosainak önérzetét. A fából esztergált és faragott babák letisztult formáikkal ábrázolják a nöket és lányokat, mintegy megtestesitve a japán nöi szépségideált. A történettudomány feltételezi, hogy a legelső darabok a Tóhokurégióból származnak, amelyeket a kései Edo-korszakban (18. század elejétôl) készitettek. Létrehozói egyszerü fafaragó mesteremberek. A kokesi az idók során több olyan funkciót magára öltött, melyek többsége a japán hitvilágban gyökerezik. Az első babák megjelenése óta jó kétszáz év telt el, s ma a kokesik népszerüsége évröl évre egyre nő. A fababa köré szervezödö kultúra szerves részei a Japánban tartott fesztiválok, szertartások és versenyek is, melyekkel ez a kézmüves termék méltó módon illeszkedik a köztudatba és a mindennapokba egyaránt. A tanulmány bemutatja a kokesik fejlödésének, szerepének évszázadokra visszatekintö változásait, illetve készitéséhez kapcsolódó szokásokat.
\end{abstract}

Kulcsszavak: Japán babák, kokesi, fababa, Japán népmüvészet, famüvesség

Japán a babák országa. Mi sem bizonyítja ezt jobban, mint a babák hihetetlenül széles választéka, mely a szigetországban az idők során kialakult, vagy épp legrégebbi babáinak keletkezési ideje, melyet a Dzsómon-korra (Kr. e. 14 500-Kr. e. 300) datálnak. A ma is ismert babák változatossága, formáiknak, használatuknak és típusaiknak gazdagsága az Edokorszak (1603-1868) alatt jött létre. A babák nem feltétlenül szükséges kellékei a mindennapi életnek, s így jól mutatják egy ország gazdasági erejét, jólétét, tükrözik lakosainak erős önérzetét; biztos jövőt s fennmaradást sugallnak egy nemzet számára. Ez a tény az egyszerű emberek számára sem ismeretlen, ahogy azt egy régi közmondás is bizonyítja, mely szerint: „Egy babák nélküli nemzet pusztulásra van ítélve" (Evans E Wolf, 2005. 17. o.). S ahogy a készítők, kezük munkája révén beleviszik alkotásaikba az életről szerzett tapasztalataikat, úgy adják vissza a babák egy társadalom s egy kor életfelfogását.

A kokesi baba a japán babák gazdag világának méltó tagja, s ma már talán Magyarországon sem teljesen ismeretlen. Egyre több programon, workshopon felbukkan, megmegjelenik kiállításokon, de találkozhatunk sziluettjével például bögréken is. De vajon tudjuk-e, mi a kokesi? Aki találkozott már vele, tudja, hogy eme szócska egy fából készült babát takar, melynek különös ismertetőjele, hogy kezek és lábak nélkül készül, teste hengeres, feje pedig gömb alakú. Méretét már nehezebb meghatározni, gyakorlatilag a néhány $\mathrm{cm}$-es példánytól az egy méteresig bármekkora lehet. A kokesi szó a legelfogadottabb vélemények szerint „fababát” vagy „kicsi babát" jelent. Manapság elsősorban dísztárgy, emléktárgy egy utazásról vagy ajándéktárgy egy kedves ismerősnek, de létrejöttének idején még más funkciókat töltött be - erről a későbbiek során szót is ejtünk majd. Érdemes azonban előbb kialakulásának körülményeit, s idejét megvizsgálnunk.

\section{Keletkezési körülmények}

Az első fababák megjelenéséhez jó 200 évre kell visszatekintenünk az időben. Bár senki sem tudja biztosan, mikor is jöttek létre, a legelterjedtebb elképzelés szerint a kései Edo-korszakban, annak is a Tenpó éveiben (1830-1844) jelentek meg elöször. Jennifer E. McDowell kokesikről szóló disszertációjában (2011) azonban az 1804-1811 közötti periódust jelöli meg, mint a fababák első megjele- 
nését. Ez az időszak a Bunka éveibe (18041818) esik bele, s az általánosan elfogadott nézetnél némileg korábbra datálja a kokesi létrejöttét. Az első írásos dokumentum mindenesetre, mely a baba létezését bizonyítja, csak az 1860-as évekből, a Szakunami környékén lévő településekről származik.

A színtér viszont egyértelmü: A kokesik hazája Japán északkeleti része, az ún. Tóhoku régió, mely az említett korszakban kezdett felfejlődni mint turisztikai célállomás. A régió bővelkedett meleg vizű forrásokban, melyet kihasználva sorra épültek a gyógyfürdőhelyek és a hozzájuk kapcsolódó fogadók. Az első időkben ugyan csak a tehetősebb társadalmi rétegek engedhették meg maguknak ezt a fajta kikapcsolódást, később azonban a gyógyfürdők (jap. onszen) vendégköre kibővült: Már nemcsak a gazdagabbakat, de a mezőgazdaságból élőket is megcélozták, akik a téli időszakban itt megpihentethették fáradt tagjaikat. S hogyan kapcsolódik össze a fürdőkultúra és a fababa története? Az összekötő kapcsot a környék hegyvidékein élő fafaragó kézművesek (jap. kidzsija) jelentik, akik fából különféle háztartási eszközöket - tányérokat, rizses tálkákat, gyertyatartókat - készítettek s árusítottak. Ők voltak azok, akik maradékfából az első kokesiket kifaragták.

\section{Hagyomány és rokonság}

A kokesi keletkezéséről a szájhagyomány is számot ad: Egy történet szerint az első kokesi formájú baba az ún. Matagoró baba volt, melyet készítőjéről, egy bizonyos Matagoró mesterről neveztek el. Ez a fafaragó mester a Tóhoku régióban, a mai Akita prefektúrabeli Nangai településhez közeli hegyvidéken gyüjtött cédrusfát (jap. szugi), s ebből készítette fababáját. Mivel a cédrus egy nagyon puha fa, az ügyes mester szabadkézzel dolgozott.

A kokesi eredetét vizsgálva nem mehetünk el egy további érdekesség mellett, mely külföldi szálakhoz füződik. A kokesi meghatározásakor ismerősen csenghetett a „fababa” kifejezés, melyet sokan össze is kapcsolhattak egy hazánkban is ismert fababával, mégpedig a matrjoskával (rus. мampëuka). Ez az orosz kézműves remek, mely több egymásba rakható, egyre kisebb babát tartalmaz, ugyan csak később, a 20. század elején jelent meg, mégis van némi kapcsolata Japánnal és a kokesivel. Egy 1896-ban Szentpéterváron tartott japán művészeti kiállításon ugyanis szerepelt egy alkotás, mely a későbbiekben ihletet adott Szergej Vasziljevics Maljutyin és Vaszilij Zvezdocskin orosz művészeknek az orosz fababa megalkotásához. A szentpétervári kiállításon bemutatott, fából készült baba egy bölcs buddhista szerzetest, Fukurumát ábrázolta. A figura a derekánál szétnyitható volt, s a belsejében található további figurák egyre fiatalabbként ábrázolták a szerzetest. Japánban emiatt úgy tartják, hogy a matrjoska létrejöttét a japánoknak köszönheti, közben azonban azt is elismerik, hogy a szóban forgó alkotást Honsú szigetén egy orosz szerzetes készítette. A kapcsolat tehát lényegében csak közvetett, azonban mindenképpen figyelemre méltó.

\section{Játékból gyűjtői darab}

A Tóhoku régióban élő fafaragó kézművesek a téli időszakban, amikor kevesebb munkájuk adódott, elkezdtek kokesi babákat készíteni. Minden valószínűség szerint először csak saját gyermekeiknek szánták őket, játékként. A babák azonban hamar népszerüségre tettek szert a fürdővendégek körében is, akik egy emléktárgyat szerettek volna magukkal vinni az utazásról. A fababák így egyre kelendőbbek lettek a gyógyfürdők környékén, s idővel azok népszerűségével vetekedtek, hozzájárulva ezzel a Tóhoku régió hírnevéhez. Ezt a felfelé ívelő korszakot azonban megakasztotta a külföldről behozott, tömeggyártott játékok elterjedése Japánban, melynek következtében a kokesi babák vesztettek népszerűségükből. Elindult viszont egy folyamat, melynek révén a fababák hagyománya új lendületet kapott: Az 1920-as években megindult a kokesik gyüjtése. Egyre többen váltak érdeklődőből komoly szándékú gyűjtővé, s a kokesi gyermekjátékból felnőtt elfoglaltsággá nőtte ki magát. Eme gyüjtői időszak csúcsát a Sóva- 
A kokesi babák kultúrtörténeti aspektusai

korszak (1926-1989) alatt, az 1955-től 1965ig terjedő évtizedben érte el. Sok mesternek ismét akadt bőven munkája, olyannyira, hogy sokszor segédekkel kellett dolgoznia - persze a fababák ára is gyorsan az egekbe szökött. A mai japán kokesi múzeumok tárgyanyagának zöme is épp az ilyen gyűjtők hagyatékából áll, s mint ilyen, egy-egy korszak „eleven kokesitörténetét" tartalmazza.

\section{A kokesi sokféle szerepe}

A kokesi először gyermekjáték, majd szuvenír volt, a 20. századra pedig a gyűjtői érdeklődés középpontjába került. De volt-e ezen kívül egyéb szerepe is? Mielőtt erre rátérnénk, érdemes elsőként szót ejteni játék voltának sokszínűségéről: A kokesi baba nem egyszerüen „csak egy baba”, melyet a kisgyermek magával hordoz, szorongat vagy kimonóba öltöztetve a hátán cipel, édesanyját utánozva. Funkcionális tárgy is, konkrétabban: rágóka, melyet egykor a kisgyermeknek fogzás idejére szántak. Ezt a szerepet az ún. kina-kina töltötte be, a kokesik egyik típusának, a Nanbu kokesinek az eredeti alakja, mely a célnak megfelelően festetlen volt, s melyet a kisbaba kezéhez méreteztek. A mai napig készítenek kina-kinát ${ }^{1}$, amely megőrizte alapformáját és finomra csiszolt felületét. Ezenkívül a kokesi baba, mint játék egy további praktikus előnnyel is bírt: Alapanyagánál fogva jóval olcsóbb és könynyebben beszerezhető volt, mint a porcelán babák, elérhetővé téve ezzel a játékot az egyszerü emberek és gyermekeik számára is. Ez a tény, illetve az, hogy a kokesi készítői is a földműves rétegből kerültek ki, bizonyítja, hogy a fababa nem az uralkodó osztályok gyermekeinek játéka és nem „művészi termék” volt. Más szóval nem egy-egy művész kreatív produktuma, hanem valódi használati tárgy.

A fababa használatát tekintve is szorosan kapcsolódik a gyógyfürdő-kultúrához. Ivor Conway (2005) szerint a kokesi, amellett

\footnotetext{
1 A mai kina-kina baba többféle méretben készül, melyek mindegyike nagyobb némileg az eredetinél. Ezek neve kikuriboko, ami „fa gyermeket” vagy „fából készült gyermeket" jelent (Funk, 2003).
}

hogy szuvenírként igen kelendő volt, egy további szerepben masszázseszközként is szolgált, amivel a vendégek vállukat masszírozhatták fürdőzés közben. Továbbá valószínűleg gyógyító erőt is tulajdonítottak neki, s ez a kialakult elképzelés összekapcsolódott az egészséges gyermekért való fohásszal, vagyis a fababa ennek a kívánságnak a megtestesítője is volt. De nem csak a mai értelemben vett szuvenírként volt használatos. Rendeltetése nem egyszerűen az ajándékozás volt. Amikor valaki kokesi babát adott gyermeke kezébe, azt remélte, ezzel az istenek kedvére tesz, s így biztosítja a jó betakarítást.

A japán hiedelemvilágban keresendő egy újabb funkció, illetve szerep, melyet ez a baba betöltött: A kokesit gyakran hozták kapcsolatba a környéken lakozó hegyi, illetve erdei szellemekkel. Úgy hitték - hisz a baba a környék fáinak felhasználásával készült -, egyegy ilyen szellem lakozik bennük. A japánok a gyermekekről úgy tartották, hogy azok életük első néhány évében egy ún. „szürke világban”, az emberek és a szellemek világa között léteznek. A kisgyermek kapcsolata a szellemi világgal ilyen módon még közvetlenebb, erősebb, $\mathrm{s}$ a fában lakozó erdei szellemeket mintegy védelmezőként állították a gyermekek mellé - egy kokesi formájában. Ahogy azonban a gyermekek nőttek, teljesen átkerültek az emberi világba, s már nem volt többé szükségük a szellemek védelmére. Így a régi, elhasznált kokesi babákat egy szertartás keretében elégették $\mathrm{s}$ a szellemeket visszaadták az erdönek. A kokesi baba lélekmegőrző szerepéről egy másik elképzelés pedig úgy tartja, maga a gyermeki lélek az, ami a babában lakozik. Amikor azonban a gyermek felnőtt korba lép, már nincs szüksége gyermeki lelkére. Felnőtt lelke veszi át testében ezt a szerepet, gyermeki lelke pedig teljesen átköltözik a fababába. A használt kokesik elégetésével ezeket a lelkeket engedték vissza a füsttel a hegyekbe, ahonnan azok származtak. A kokesi és a gyermek láthatóan szorosan kapcsolódnak egymáshoz, mint ahogy ezt egy további szerepkör is bizonyítja: Egyesek úgy vélik, a fababa egy mementó az anya számára, aki elvesztette vagy megölte magzatát ínséges időszakokban. 
A kokesi egy újabb értelmezésben amulett szerepet is betölthet. Védelmezőként elüzi a bajt, illetve megvéd a tűzesetektől, így sok otthonban megtalálható volt egy-egy példánya. Utóbbira magyarázatként alapanyaga szolgál: A kokesit vagy fejrészét ugyanis leggyakrabban az ún. mizuki fából (magy. somfa) készítették, ami nedvszívó tulajdonsága révén a hit szerint különösen alkalmas az otthonok védelmére, a tűzesetek megelőzésére. A mizuki fa eme tulajdonságát nevében is hordozza, hisz a szó lefordítva „víz fát” jelent.

A kokesi fentiekben felsorolt szerepei az idők során fokozatosan alakultak ki s járultak hozzá a teljes szimbólumkörhöz, melyet ez a tárgy ma képvisel. S épp ez a sokszínű szimbolika engedi meg, hogy egy-egy értelmezés egy adott társadalmi és élethelyzetben újra és újra felszínre kerülhessen, s aktuális jelentést és jelenlétet adjon a fababának. Példaképp említendő a kokesi mementószerepe, mely az 1960-as években éledt újra, amikor japánban elterjedt az abortusz. De alakja is okot adott az aktualizációhoz: A mai fiatal generáció számára ez a baba ugyanis egy burkolt kifejezés, mely egy szexuális segédeszközt takar.

\section{Alapanyagok és készítés}

Mai modern világunkban ugyan már gyárilag, gépek segítségével is készülnek példányok, a kokesi azonban eredendően a fafaragó mester saját kezének munkája. A méretre vágott fa egy esztergapadra helyezve, különböző méretű vésők és csiszolópapírok segítségével ölt formát. Maga az esztergapad, ez a központi szerepet játszó eszköz is alapos fejlődésen esett át az első fababák elkészülte óta. Akkoriban még egy kizárólag kézzel hajtott szerkezet volt, aminek mozgásba lendítése több embert igényelt: Míg az egyik fafaragó meghajtotta a szerkezetet, a másik felhasználhatta a forgást a fadarab megmunkálására. De akár ezt a kezdeti formát, akár a mai, elektromos meghajtású esztergapadot vizsgáljuk, a munka mindegyikkel komoly fizikai erőt, izommunkát s emellett komoly koncentrációt igényel. $\mathrm{S}$ a munkamenetnek nem csupán ez a része, de az előmunkálatok, maga a fa kitermelése és méretre szabása is a mesterek feladata volt. A mesterek nagy része a mai napig még a faragáshoz szükséges eszközöket is maga készíti, a régi időkben pedig ez minden bizonnyal általános volt. Mielőtt a kokesi egyáltalán alakot ölthet, a felhasználandó fát elő kell készíteni, vagyis szárítani kell. A folyamat lassú, hónapokon vagy akár éveken át érlelik a megfelelő állag elérése érdekében. Amikor azonban elérkezik az idő, a fa végre átalakulhat. $\mathrm{Ha}$ a kokesikészítő-mester a munkát elejétől a végéig, a faragástól a festésig maga végzi, sokszor két különböző napra teszi ezt a két fontos mozzanatot. S ez természetes is, mert az esztergapad használata során elgémberedett kezei nem tudnák egyenesen tartani az ecsetet. A fababa pontos elkészítési sorrendjéről nehéz beszámolni, hiszen ez mind a mestertől, mind a kokesi típusától egyaránt függ. Egyes babatípusok egy, míg mások két vagy akár több darabból is állhatnak. Fontos megjegyezni viszont, hogy a kokesik többségén látható a mester szignója ${ }^{2}$, ami azért egyedülálló, mert a japán babakészítő-iparban egyáltalán nem szokás aláírni az elkészült darabot. A babát ezenkívül végül viaszréteggel is ellátják, amit ki is fényesítenek. A viaszozás azonban inkább a hagyományos kokesire jellemzö, a modern kokesit inkább lakkozzák, ahol a lakk típusa, vastagsága szintén többféle lehet.

Az előzőekben szót ejtettünk már a fa megmunkálásáról, de nem említettük még, milyen típusú fával is dolgoznak a fafaragó mesterek. Hagyományosan a fababa, részben vagy egészben a már korábban említett mizukiból készül, de mellette számos egyéb, a környéken honos fát is felhasználnak a készítők. Ilyen például a japán juhar (jap. itaja kaede), a japán hóvirágfa (jap. haku’un boku), a kamélia (jap. cubaki), de alapanyagként szolgál a cseresznyefa (jap. szakura) és a japán körte (jap. nasi) is, valamint készülnek babák japán hamisciprusból (jap. hinoki), császárfából (jap. kiri) és japán gyertyánszilből (jap.

\footnotetext{
2 Ha több mester is dolgozott az adott fababán, a festő kézjegye kerül fel a kokesire. (Uo.)
} 
A kokesi babák kultúrtörténeti aspektusai

kejaki) is. A felhasznált fák felsorolásán kívül még számos érdekes tényről lehetne írni, mint például a kokesi babák fényérzékenységéről, mintáik bámulatos gazdagságáról vagy akár az alkalmazott színvilágról, eme munka terjedelme azonban sajnos nem engedi ezek részletesebb bemutatását.

\section{A kokesi típusairól}

Talán nem is gondolnánk, de mára a kokesinek sokféle fajtája alakult ki. Mivel már a kezdetektől több fafaragó mester is foglalkozott kokesikészítéssel, a fababák - alapformájukat, a gömbölyű fejet és a hengeres testet leszámítva - természetesen nem voltak egyformák. Számos gyógyfürdő környékén készítettek kokesit Tóhokuszerte, s ez a földrajzi távolság, illetve a mesterek által a babába vitt egyediség idővel csoportokra bontotta a kokesit. Az egyediség, melyre a mesterek törekedtek, párosult a hagyománnyá alakítás szándékával, melynek ékes bizonyítékai a kokesit készítő fafaragó mesterek családilag vezetett katalógusai. Eme névjegyzékekbe a családok - hisz a mesterség apáról fiúra szállt - gondosan feljegyezték az illető mester utódát, s egy-egy mester újításait, mely újítások idővel aztán összegződtek, s a kokesik egy-egy új családja alakult ki belőlük. Az egyedi ismertetőjegyekkel rendelkező fababák így saját elnevezést is kaptak. Nevük többségében egyezik a gyógyfürdő nevével, aminek közelében készítették őket. A legrégebbi múltra visszatekintő típusok az ún. Tógatta- és Naruko/Narugo-típus, melyek már az Edo-korszak végére kialakultak. A Taisó-korszak (1912-1926) végére pedig immár a kokesik mind a tíz, illetve tizenegy ma is ismert típusa létrejött. A tizenegy fó típus pedig a következő: Tógatta-, Naruko/Narugo-, Kidzsijama-, Nanbu-, Cucsiju-, Szakunami-, Jamagata-, Cugaru-, Hidzsiori-, Zaó- és Jadzsiró-típus. Eltérések a számolásban azért akadnak, mert a kokesik számos típusának ún. altípusai is kialakultak, s egyesek erősen eltérő stílusjegyeik révén mára már új, önálló típusnak számítanak. A legjobb példa erre az ún. Szakunami-
Jamagata-típus, mely a fent említett felsorolásban is külön szerepel, azonban eredendően egybe tartozott. De megemlíthetjük itt az ún. Nakanozava kokesit is, mely alapvetően egy altípus, népszerüsége viszont a "nagy típusokkal" vetekszik.

A kokesi fentebb említett tizenegy típusa, ha testének hengeres mivoltát nézzük, egységesnek mondható. Mégis meg kell említeni három különleges alakot, mely a kokesi több fajtájánál is megtalálható. Az egyik ilyen alak az ún. edzsiko, mely a hagyományos kokesi Tógatta-, Naruko-, Zaó-, Cuchiju-és Jadzsiró-típusainál jelenik meg elsősorban, illetve olykor a Nakanozava-altípusnál. Az edzsiko jelentése „baba kosárban”, vagyis ez egy kosárban ábrázolt kokesi³ ${ }^{3}$ Ez a forma egy másik játékból, az ún. izumekoból ${ }^{4}$ ered. Az izume egy fonott kosárfajta, eredetileg a rizs melegen tartására használták. Később a földmüvesek, akik gyermeküket kisbaba korában magukkal vitték a földekre, ebben a kosárban hagyták azokat bebugyolálva, a földek szélén, amíg ők dolgoztak. Ezt a szokást ábrázolja az izumeko és az ebből a játékból ihletet merített edzsiko kokesi. A másik alak az ún. nemariko kokesi, mely a hagyományos kokesinél egyedül a Naruko-típusra jellemző. Ez egy ülö kokesi, mely harang alakú, teste pedig enyhén elvékonyodik a vállrésznél. A harmadik speciális alakkal rendelkező fababa az ún. komori kokesi vagy gyermekvigyázó kokesi. A fababa hátán megjelenő gyermek azt ábrázolja, hogyan hordták a japán nők gyermekeiket. A három különleges alak között ez a legnépszerűbb, ugyanis mind a hagyományos típusoknál, mind pedig a modern kokesiknél megtaláljuk képviselőit.

3 Letöltés: https://darumadollmuseum.blogspot. hu/2005/03/kokeshi-1.html (2016. 03. 28.)

${ }^{4}$ Az izumeko egy japán babatípus, az 1910-es évek elején terjedt el a Jamagata prefektúrabeli Curuoka környékén. Legrégebbi darabjait makkhéjból készítettek, melybe egy kicsiny babát tettek. Később az izume-kosár egy kicsinyített másába került egy pici baba, melyet egy darabka gyapottal borítottak. A kosárka szélére pici játékokat is akasztottak, ugyanúgy, ahogyan a gyermeküket védő izume-kosár mellé is helyeztek játékokat (Evans $\mathcal{E}$ Wolf, 2005. 86. o.). 
A kokesi családjai folyamatosan alakultak, bővültek, gazdagítva ezzel a fababák formaés színvilágát, illetve méreteit ${ }^{5}$. A második világháború utáni időszakban azonban újabb változások következtek. Az ipar és a technológia rohamos fejődése utat nyitott egy új mozgalomnak, mely a fababák csoportosításának újragondolását vonta magával. Az új trend, mely egyre inkább terjedt Japán-szerte, a fababák készítésének és megformálásának „kreatív” újragondolása volt. A kokesikészíto”mesterek gyakorlatilag mindent máshogyan csináltak. Üjragondolták a formákat és a színvilágot: Babáik olykor aszimmetrikus alakot öltöttek és eddig nem használt árnyalatú és intenzitású színekben pompáztak. Mintáik megváltoztak: A legtipikusabb példa erre a babák testét borító kimonóminta, mely szinte minden modern kokesin megtalálható ${ }^{6}$. Újdonságként ezek a babák olykor kiegészítőket is kaptak, például kalapot vagy ernyőt, lehetett kezük vagy lábuk, vagy akár megjelenésük is lehetett teljesen más: A klasszikus emberalak helyett olykor állatfigurák vagy egy-egy karakter, például légiutas-kísérő vagy kalauz alakját öltötték magukra. A kokesi eddig kialakult típusai túlnyomó többségben női alakot ábrázoltak, mintegy szimbólumként a szépségideált kifejezve, az új trend azonban már nagyobb arányban ábrázolt férfi-, illetve fiúalakot is, szamurájokat vagy akár szerzeteseket. Egyes példányokat ráadásul már nem, vagy csak részben kézzel készítettek; megjelentek a tömeggyártott kokesik (jap. singata kokesi) is. Az újfajta kokesik immáron kizárólag szuvenírként szolgáltak. Ez az új mozgalom teljesen megváltoztatta a fababákról kialakult képet. Ez ösztönzést adott a művé-

\footnotetext{
${ }^{5}$ Utóbbiról elmondhatjuk, hogy a kezdeti korszakban, amikor a babák még főleg gyermekjátékként szolgáltak, átlag 12, 18, vagy $24 \mathrm{~cm}$-esek voltak. A Taisó- és korai Sóva-korszakra - amikor gyűjtésük megkezdődött azonban már jóval többféle méretben készültek. Nagyságuk elérhette az 1,22 m-t is, gyüjtői igény szerint (Funk, 2003).

6 A kimonóminta a Kidzsijama-típusra jellemző, mely mintázat valószínűleg a korai Sóva-korszakban alakult ki, s vált fokozatosan eme típus ismertetőjegyévé. Valószínűleg ez volt az a típus, mely mintául szolgált az új mozgalom babáinak stílusát illetően. (Uo.)
}

szeknek is, hogy egyedi, egyszeri darabokat alkossanak, mely tisztán a művész képzelőerejét és ügyességét testesíti meg $\mathrm{s}$ művészi szintre emeli ezt a szuvenírt és egykori játéktárgyat. Az így készített kokesiket pedig hamarosan, egy új kategóriát jelölendő, kreatív kokesikként (jap. szószaku kokesi) kezdték el emlegetni.

A kokesi újonnan megjelent nagy csoportja tehát, mely, mint láttuk, hamarosan több kisebb csoportra tagolódott tovább, a fent említett tulajdonságai révén alapvetően tért el az addig készített kokesiktől, ennek megfelelően pedig szükségessé vált a két nagy csoport névbeli megkülönböztetése is. Az eredeti, az Edo-korszakban kialakult babákat ezért a hagyományos kokesi (jap. dentó kokesi) megjelöléssel illették. Ezzel szemben az új kategóriákat (singata, szószaku kokesi, illetve egy harmadik kategória, az ún. szuvenír kokesi) egységesen a modern kokesi elnevezéssel jelölték, s ezzel két nagy csoportot hoztak létre a fababák világán belül. Szintén érdekfeszítő a fababák családjainak, a két nagy csoporton belüli kisebb csoportoknak a fent leírtaknál is részletesebb ismertetése, jellemzése, ettől azonban helyszűke miatt, ezúttal sajnos el kell tekintenünk.

\section{A kokesi köré szerveződő események}

A kokesi Japánban élő hagyományt képez, s mint ilyen, ünnepek és szertartások is kötődnek hozzá. Ilyen az évente január elsején Jadzsiróban tartott kokesi-ünnep, vagy a már korábban említett kokesi-áldozatbemutatás, amit egy szertartássorozat keretében végeznek Naruko városában, minden év szeptemberének első napjaiban. A narukobeli szertartásokhoz emellett egy kokesiverseny is tartozik, ahol a müvészek legjobb babáikat mérettethetik meg, s az első helyezett díját magától a miniszterelnöktől veheti át. A babák egy része a helyi múzeum kiállítási tárgyaként lesz megtekinthető, egy részüket pedig a mesterek felajánlják a szentélynek, mely 7000 kokesi babával büszkélkedhet. A Narukoban tartott kokesiversenyen kívül rendeznek még versenyt május elsején Siroisiben (Nemzeti 
A kokesi babák kultúrtörténeti aspektusai

Kokesi Verseny), illetve június végén Tokióban (Szószaku-verseny) is, minden év november 1-jén pedig Sibukavában rendeznek kiállítást, mely a kreatív kokesiket mutatja be.

A kokesi baba gyakorlati felhasználásával és gazdag, szakrális szimbolikájával igazán érdekes eleme nemcsak a japán babák világának, de magának a japán kultúrának is. Bár kétszáz évével mondhatni fiatal jelenség, mégis komoly hagyomány szerveződött köré. Újra és újra megújulni képes, sokrétű mondanivalója életerőssé teszi, s nemcsak a régebbi korok emberei, hanem a mai fiatalabb generáció számára is értéket képvisel. Helyet kapott a japán ember tudatalattijában, $\mathrm{s}$ visszafogott eleganciájával és bájosságával természetes kísérője a mindennapoknak.

\section{Utószó}

Eme tanulmány nem törekszik egy-egy hipotézis felállítására, illetve azok megválaszolására. Megírásában a szerzőket az a szándék vezérelte, hogy a tanulmány bemutatást engedjen egy ikonikus figura és igen sokoldalú tárgy világába, melyet joggal tekinthetünk a szigetország kultúráját megjelenítő imázstárgynak, a Japánt jellemző számtalan jelkép egyikének. Bár a kokesi baba egyértelmű céllal jött létre, ti. játéktárgy és szinte azonos időben szuvenír szerepét töltötte be, mind keletkezési körülményei körül, mind pedig szerepét illetően számtalan hiedelem terjedt el. Ezen hiedelmek természetesen nem köthetők egyetlen emberhez, de még a fababákról a későbbiek során, szándékosan kialakított kép sem köthető minden esetben konkrét személyhez. Emiatt csak a legkivételesebb esetekben hivatkozhatunk egy-egy konkrét névre, szerzőre, s legtöbbször be kell érnünk a hagyomány, általános feltételezés, illetve a hiedelemvilágból eredő közfelfogás adta magyarázatokkal. A tanulmányban elhangzott elméletek egyike sem bizonyított tehát egyértelmű módon, viszont cáfolásukra sem sorakoztatható fel elegendő érv. Eme homályosság ugyan zavaró lehet, táplálja és erősíti azonban a kokesi babáról kialakított - igen sokszínű - képet, valódi jelenséggé téve ezt az egyszerü fababát.

Hazánkban ugyan foglalkoznak a japán babák világával, a játékokkal és azok történetével, a kokesi babáról azonban jelenleg nem érhető el olyan célzott tanulmány vagy írás, mely eme fababáról magyar szemszögből tudósítana. A tanulmány emiatt angol nyelvü forrásokból táplálkozik.

\section{Felhasznált irodalom}

Conway, I. (2005): History of kokeshi wooden dolls from Japan.

URL: http://ezinearticles.com/?Historyof - Koke shi - Wooden - Dolls - from Japan\&id=67515 (2016. 03. 25.)

Evans, M. \& Wolf, R. (2005): Kokeshi: Wooden treasures of Japan, a visual exploration. (1. ed.) Vermillion Publishing, Carmel, California.

Funk, Sh. (2003, early winter): Michi no ku dentou kokeshi. (Northern Japan traditional kokeshi.) Variations on a theme. Ningyo Journal. URL: http://www.lasieexotique.com/mag kokeshi/mag_kokeshi.html (2016. 03. 25.)

Hackethal, A. (2012): Japanese kokeshi folk toys. URL: http://www.designboom.com/art/ kokeshi/ (2016. 03. 25.)

Kitamura T. (1988): The dolls of Japan. Shapes of prayer, Embodiments of love. The Japan Foundation, Tokyo.

Kokeshi dolls: More than a pretty face. (2011) URL: https://furugistarjapan.wordpress. com/2011/01/24/japanese-kokeshi-dollsmore-than-a-pretty-face/ (2016. 03. 25.)

Larsen, Sh. (é. n.): Kokeshi history.

URL: http://www.kokeshidesigns.com/pages/ kokeshi-history (2016. 03. 25.)

McDowell, J. E. (2010): „Kokeshi: Shifting signifiers and wooden tradition", Tohoku Anthropological Exchange, 9., 1-34.

McDowell, J. E. (2011): Kokeshi: Continued and created traditions. Motivations for a japanese folk art doll.

URL: http://d-scholarship.pitt.edu/9089/1/ mcdowell_etdPitt2011.pdf.pdf (2016. 03. 28.)

Okazaki Manami (2015): Kokeshi. From Tohoku with love. (2. ed.) Kingyo, Hong Kong. 


\section{Internetes oldalak}

http://kokeshi-rocobee.blogspot.hu/ (2016. 03. 25.)

ht tp: / / matryosh ka.co.id/about matryoshka/?printable $=1$ (2017. 10. 11.)

http://www.examiner.com/article/traditionaljapanese-culture-kokeshi-dolls (2016. 03. 25.)

http://www.janm.org/exhibits/kokeshi/ traditional/ (2016. 03. 25.)

http://www.japanese-doll.biz/group/kokeshidoll.html (2016. 03. 25.) http://www.japanya.co.uk/kokeshi.aspx (2016.

03. 25.)

http://www.madehow.com/Volume-6/ Matryoshka-Doll.html (2017. 10. 03.)

http://www.thejapaneseshop.co.uk/what-arekokeshi-dolls.html (2016. 03. 25.)

http s: / / d arumadollmus eu m. blog spot. hu/2005/03/kokeshi-1.html (2016. 03. 28.)

\section{Cultural aspects of kokeshi dolls in the history of Japan}

Japanese culture of dolls is rooting into millenia showing the cultural and economic strength of Japan as well as dignity of its inhabitants. Mastery of woodworkers show dolls embodying the ideal beauty of women and girls. It is believed that the first dolls were made in the late Edo-era (the beginning of the $18^{\text {th }}$ century) in Tóhoku region by humble woodworkers. During centuries of kokeshi dolls they get more and more popular. In Japan there are festivals and rituals being held around these small wooden dolls presenting the old and modern cultural bounding. The study presents the world of kokeshi dolls, their evolution as well as their changes related to the beliefs of Japanese people.

Keywords: Japanese dolls, kokeshi, wooden dolls, Japanese folk arts, woodworking

Tóth-Vásárhelyi Réka és Rácz Ibolya (2019): A kokesi babák kultúrtörténeti aspektusai. Gyermeknevelés, 7. 1. sz., 48-53. 


\section{Kokesi babák}

(a fotókat Tóth Anita készítette)
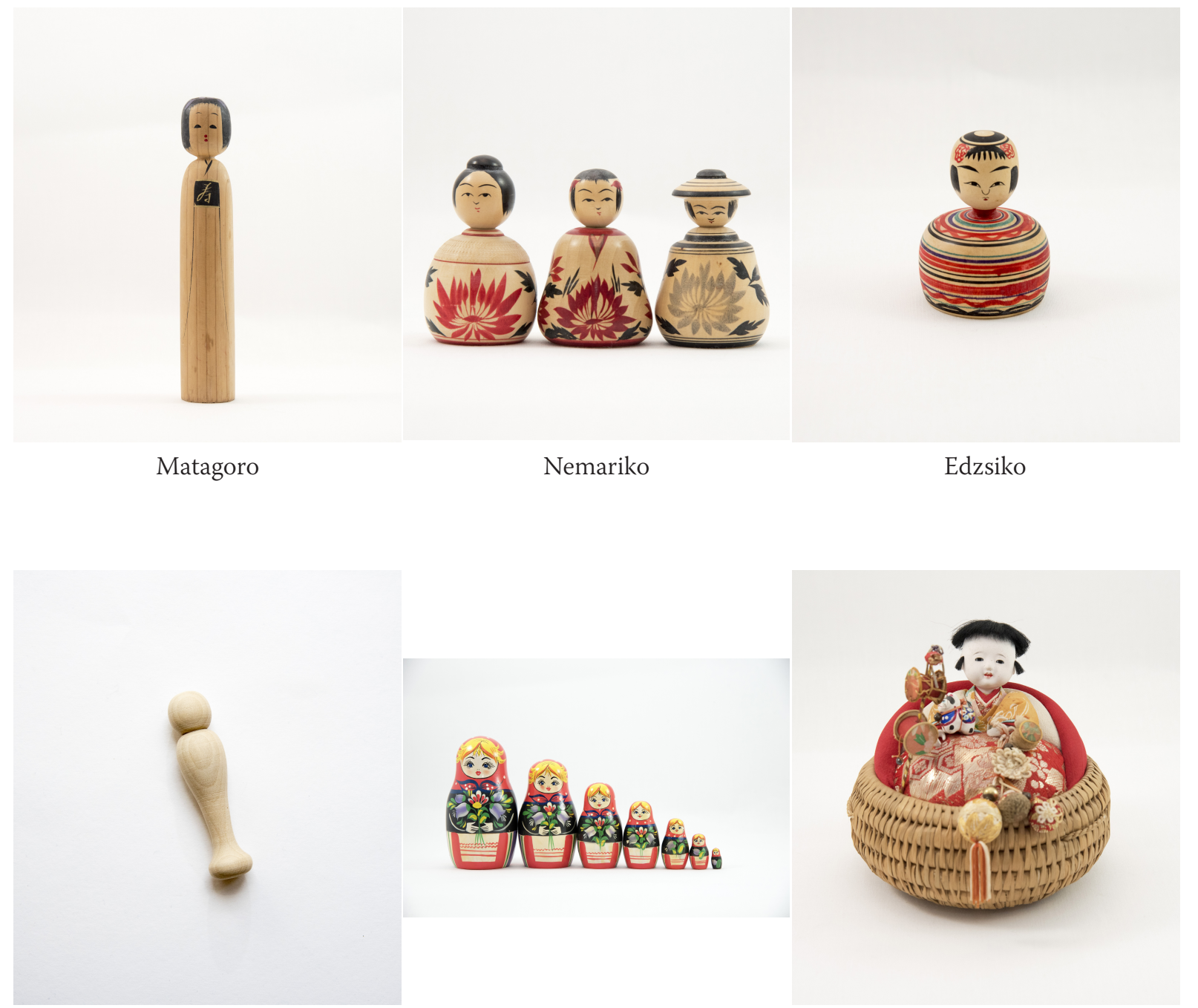

Kina-kina

Matrjoska

Izumeko

\section{Dento kokesi babák}

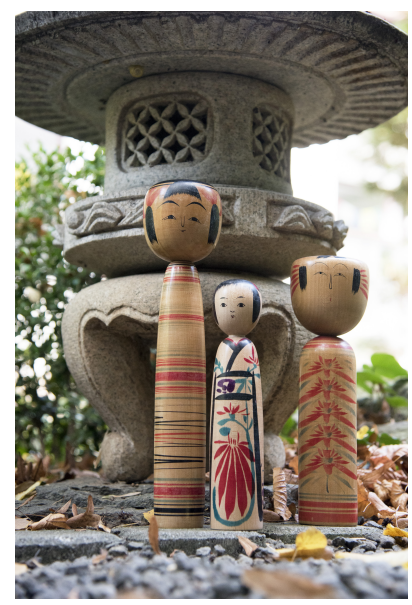

(b) Cucsiju - készítette: Vatanabe Szadami,

(k) Kidzsijama - készítette: Onodera Maszanori,

(j) Zaó - készítette: Abe Cunekicsi 